\title{
Advanced Therapies in Pediatric Endocrinology and Diabetology
}

\author{
Editors: Marco Cappa, Stefano Cianfarani, \\ Lucia Ghizzoni, Sandro Loche, Mohamad Maghnie
}

Dealing with current hot topics, this book aims to provide an update on advances in the treatment of endocrine disorders. The chapters cover innovative therapeutic approaches to type 1 diabetes, such as artificial pancreas and islet transplantation. Additionally, novel pharmacological interventions for patients with obesity and the metabolic syndrome, as well as with adrenal and gonadal disorders are provided. Furthermore, recent developments in growth-promoting therapies, such as the C-Type natriuretic peptide analog to treat achondroplasia, as well as antioxidant and gene replacement therapies in patients with adrenoleukodystrophy, are described. Worldwide renowned experts share their experience and cutting edge research in Advanced Therapies in Pediatric Endocrinology and Diabetology, which makes it a useful and interesting resource for every pediatric endocrinologist, not only those active in clinical research, but also those involved in the management of children with endocrine diseases in daily practice.

\section{CONTENTS}

Preface

Toward Automation of Insulin Delivery - Management Solutions for Type 1 Diabetes: Nimri, R.; Phillip, M.

Islet Transplantation in Pediatric Patients: Current Indications and Future Perspectives: Bertuzzi, F.; Antonioli, B.; Tosca, M.C.; Galuzzi, M.; Bonomo, M.; Marazzi, M.; Colussi, G. Glucagon-Like Peptide-1 Receptor Agonist Treatment for Pediatric Obesity: Kelly, A.S. Docosahexaenoic Acid and Its Role in G-Protein-Coupled Receptor 120 Activation in Children Affected by Nonalcoholic Fatty Liver Disease: Della Corte, C.; Mosca, A.; lonata, A.; Nobili, V.

Noninvasive Prenatal Diagnosis of Congenital Adrenal Hyperplasia: Khattab, A.; Yuen, T.; Sun, L.; Yau, M.; Barhan, A.; Zaidi, M. ; Lo, Y.M.D.; New, M.I.

Recent Advances in Hydrocortisone Replacement Treatment: Mallappa, A.; Debono, M. Experience with the Histrelin Implant in Pediatric Patients: Eugster, E.A.

Different Medications for Hypogonadotropic Hypogonadism: Rastrelli, G.; Vignozzi, L.; Maggi, $M$.

Long-Acting Growth Hormone: An Update: Saenger, P.H.; Mejia-Corletto, J.

C-Type Natriuretic Peptide Analog as Therapy for Achondroplasia: Legeai-Mallet, L.

Therapeutic Neuroendocrine Agonist and Antagonist Analogs of Hypothalamic Neuropeptides as Modulators of the Hypothalamic-Pituitary-Gonadal Axis: Newton, C.L.; Anderson, R.C.; Millar, R.P.

Aromatase Inhibitors in the Treatment of Short Stature: Hero, M.

Gene Therapy for Rare Central Nervous System Diseases Comes to Age: Aubourg, P. Novel Therapeutic Targets and Drug Candidates for Modifying Disease Progression in Adrenoleukodystrophy: Pujol, A.
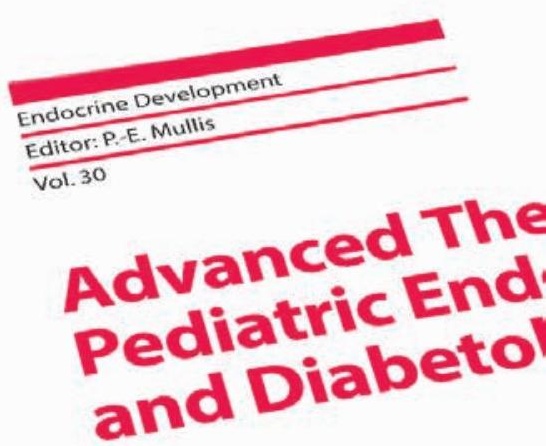

Editors
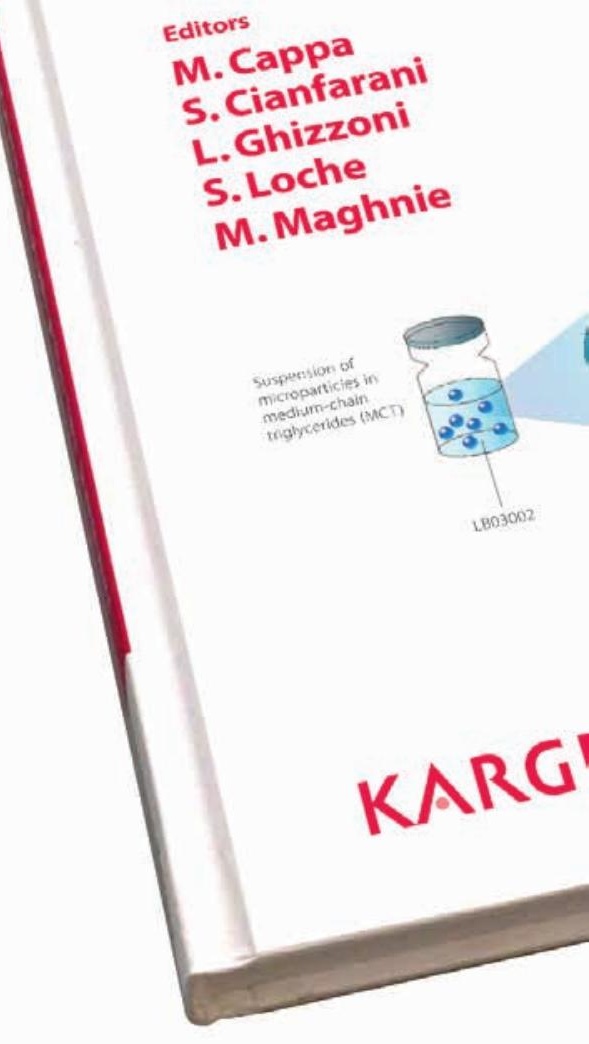


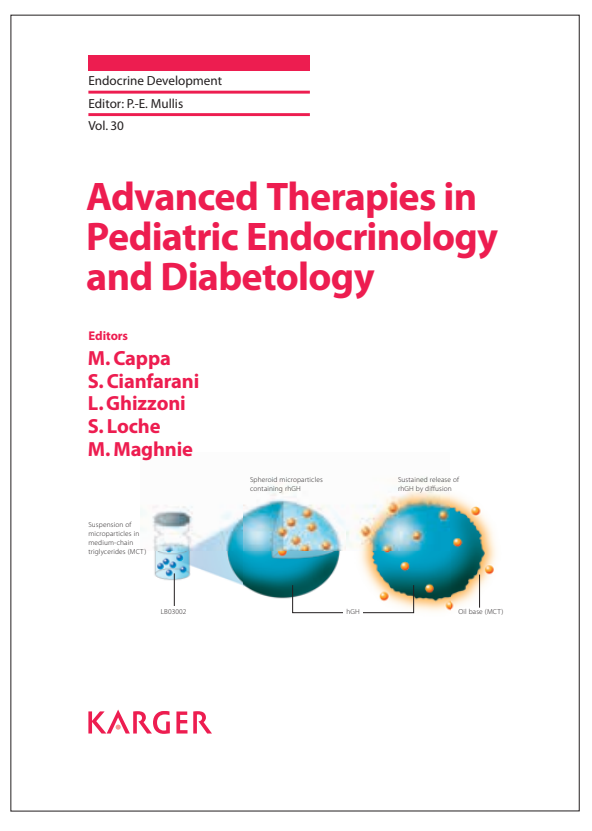

Endocrine Development, Vol. 30

\section{Advanced Therapies in}

\section{Pediatric Endocrinology}

and Diabetology

Editors: Cappa, M.; Cianfarani, S. (Rome);

Ghizzoni, L. (Turin); Loche, S. (Cagliari);

Maghnie, M. (Genoa)

VIII + 166 p., 27 fig., 6 in color, 10 tab., 2016

CHF 168.00 / EUR 157.00 / USD 198.00 (hard cover)

CHF 202.00 / EUR 188.00 / USD 238.00 (online)

Online version for institutional purchase

ISBN 978-3-318-05636-5 (hard cover)

e-ISBN 978-3-318-05637-2

\section{FIELDS OF INTEREST:}

Endocrinology; Pediatrics; Diabetes, Obesity, Pediatric Endocrinology

\section{Further publications in the field}

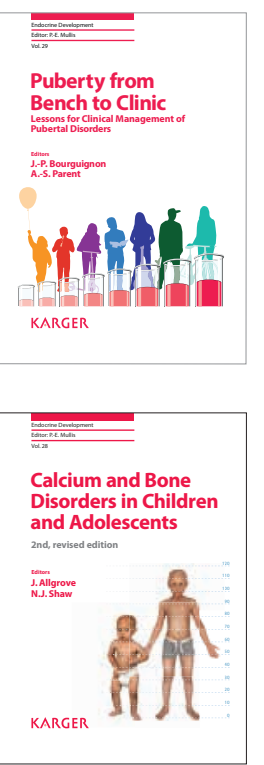

Vol. 29

Puberty from Bench to Clinic

Lessons for Clinical Management

of Pubertal Disorders

Editors: Bourguignon, J.-P.; Parent, A.-S. (Liège)

$X+276$ p., 15 fig., 5 in color, 25 tab., 2016

CHF 198.00 / EUR 185.00 / USD 233.00 (hard cover)

CHF 238.00 / EUR 222.00 / USD 280.00 (online)

ISBN 978-3-318-02788-4 (hard cover)

e-ISBN 978-3-318-02789-1

Vol. 28

Calcium and Bone Disorders

in Children and Adolescents

2nd, revised edition

Editors: Allgrove, J. (London); Shaw, N.J. (Birmingham)

VIII + 434 p., 152 fig., 22 in color, 43 tab., 2015

CHF 247.00 / EUR 231.00 / USD 291.00 (hard cover)

CHF 296.00 / EUR 277.00 / USD 349.00 (online)

ISBN 978-3-318-05466-8 (hard cover)

e-ISBN 978-3-318-05467-5

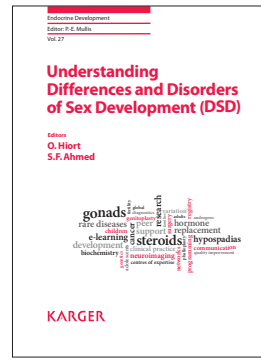

\section{Vol. 27}

Understanding Differences

and Disorders of Sex Development (DSD)

Editors: Hiort, O. (Lübeck); Ahmed, S.F. (Glasgow)

$\mathrm{X}+300$ p., 28 fig., 12 in color, 26 tab., 2014

CHF 198.00 / EUR 185.00 / USD 233.00 (hard cover)

CHF 238.00 / EUR 222.00 / USD 280.00 (online)

ISBN 978-3-318-02558-3 (hard cover)

e-ISBN 978-3-318-02559-0

\section{Endocrine Development}

Series Editor: Mullis, P.-E. (Bern)

ISSN 1421-7028/ e-ISSN 1662-2979

Listed in MEDLINE/PubMed

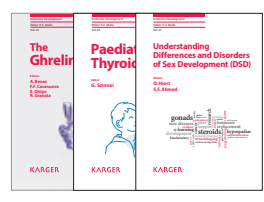

Vol. 1-26

available, please ask for details

Online version for institutional purchase

Prices subject to change, VAT not included

EUR price for eurozone countries,

USD price for USA and Latin America only

www.karger.com/endev
Orders can be placed at agencies, bookstores, directly with the publisher, or with any Karger distributor.

\section{e: orders@karger.com}

S. Karger AG, P. O. Box, 4009 Basel (Switzerland) f: +41613061234

USA: S. Karger Publishers, Inc., 26 West Avon Road, P.O. Box 529, Unionville, CT 06085, Toll free: +1-800-828-5479

Germany: S. Karger GmbH, 79095 Freiburg

France: Enter \& Read, Albertine Luginbuhl, 75014 Paris

Japan: Karger Japan, Inc., Tokyo 105-0012

South East Asia, China and Taiwan: Karger China, Shanghai 200001

Russian Federation: World of Periodicals, Moscow 125190

For details and further representatives and agencies see:

www.karger.com/worldwide
Library Recommendation

Dear Librarian

I have reviewed Advanced Therapies in Pediatric Endocrinology and Diabetology and would like to recommend it for your library

Recommended by:

Department:

Date:

Signature:

ebooks are available on amazon
Google play 